\author{
Malika Arsanukaeva \\ (Akademia Prawnicza w Moskwie) \\ (przekład z j. rosyjskiego: Artur Sadecki, UMCS)
}

\title{
Kara więzienia dla górali z północnego Kaukazu (XIX-początek XX w.)
}

\author{
Imprisonment for mountaineers from the North Caucasus \\ (the nineteenth-early twentieth century)
}

\begin{abstract}
STRESZCZENIE
W niniejszym artykule została podjęta próba omówienia niektórych aspektów funkcjonowania górali kaukaskich w Imperium Rosyjskim. Jednak wiele niezbadanych źródeł i materiałów, rola górali kaukaskich w historii Rosji wpływają na konieczność bardziej wnikliwych badań i analiz. Na szczególne zainteresowanie zasługują geograficzne ustalenie miejsc zesłania i odbywania kar więzienia przez górali, liczba aresztowanych i zesłanych, wiek ukaranych, narodowość, czasokres i warunki odbywania kar.
\end{abstract} słanie

Słowa kluczowe: Imperium Rosyjskie, Kaukaz, Czeczeni, Ingusze, więzienie, ze-

Stosowanie takich rodzajów kar, jak osadzenie w twierdzy, więzienia i forty, zesłanie i przymusowe osiedlenie, w stosunku do górali z Północnego Kaukazu ${ }^{1}$, czyli nowych poddanych Imperium Rosyjskiego, jest tematem, który dotychczas został zbadany w niewielkim stopniu pomimo tego, iż posiada dużą wartość poznawczą i naukową.

W historii Rosji wraz z rozwojem służby policyjnej rozwinął się również system wymierzania kar związanych z pozbawianiem wolności. W aktach prawnych z XII-XIII w. można już spotkać przepisy o zamykaniu przestępców w piwnicach lub „porubach" ${ }^{2}$ przy jednoczesnym zaku-

${ }^{1} \mathrm{~W}$ tekście występują zamiennie terminy: górale z Północnego Kaukazu, górale kaukascy. Pominięto rzadziej występujące określenie "gorcy" - A. S.

${ }^{2}$ Ros. porub - w dawnej Rusi drewniana budowla z bierwion, w której umieszczano więźniów - A. S. 
waniu ich w kajdany. Badacze przypuszczaja, że tego typu kary pojawiły się znacznie wcześniej, we wskazanym czasie zostały tylko skodyfikowane. $W$ miarę dalszego rozwoju aparatu represji więzienie odgrywa coraz większą rolę i staje się najważniejszym rodzajem kary dla przestępców. Jak wiadomo, jest ono przewidziane w Sudiebniku ${ }^{3}$ z 1550 r. (np., art. 4, $6,7)^{4}$. W Ułożeniu Soborowym ${ }^{5}$ z 1649 r. kara więzienia zostaje już przewidziana w 40 przypadkach, z których każdy jest ściśle określony. Po raz pierwszy na mocy prawa zostaje wprowadzony podział wyroków pozbawienia wolności na czas określony i nieokreślony ${ }^{6}$.

W XVII w. nie istniał w Rosji pojedynczy organ zarządzający więzieniami. Znajdowały się one pod zarządem poszczególnych prikazów ${ }^{7}$ (np. Strieleckiego, Ziemskiego itp.). Na miejscu więzieniami zarządzali wojewodowie. W tamtym czasie więzienia dzieliły się na stałe i czasowe. Pierwsze $\mathrm{z}$ nich znajdowały się $\mathrm{w}$ niektórych klasztorach i miastach (Murom, Ustiug, Szuja, Wirchoturie itd.). W Moskwie istniało więzienie „Brażnaja tiurma"8.

Wraz z podbojem Syberii $\mathrm{w}$ XVII w. zamiast kary typu wygnanie z ziemi zostaje wprowadzone zesłanie. Jednak Ułożenie Soborowe z 1649 r. przewiduje tę karę jedynie w nielicznych przypadkach ${ }^{9}$.

Do początku XVIII w. system więzienny praktycznie się nie zmienia. W Wojenno-Karnym Kodeksie Piotra I (tzw. Woinskij artikuł) z 1715 r. kara więzienia zostaje przewidziana za cały szereg przestępstw (przeciwko porządkowi publicznemu, przeciwko czci, za nieumyślne zabójstwo itd. $)^{10}$. Wraz z podziałem terytorium państwowego na gubernie ${ }^{11}$ więzienia mi zaczynają zarządzać gubernatorzy, a "cełowalników"12 i stróżów zastępują dozorcy służb policyjnych.

${ }^{3}$ Sudiebnik - zbiór praw (termin obecny również w historii prawa polskiego). 1550 r. - Sudiebnik Iwana IV - A. S.

${ }^{4}$ Zob. В. Ю. Титов, Хрестоматия по истории государства и права России, Москва 1998, s. 43.

${ }^{5}$ Zbiór praw z XVII w. związany z reorganizacją całego państwa - A. S.

${ }^{6}$ B. Ю. Титов, op.cit., s. 50-147.

${ }^{7}$ Centralne urzędy państwowe istniejące w Rosji od XV wieku - A. S.

8 Zob. http://drink.dax.ru/turma/turem_30.shtml. [dostęp: 8 V 2013 r.]; Miejsce, w którym przetrzymywano osoby w stanie nietrzeźwym - A. S.

${ }_{9}^{9}$ B. Ю. Титов, op.cit., s. 43.

${ }^{10}$ Ibidem, s. 169-199.

${ }^{11}$ Jednostka podziału administracyjnego państwa. Dalej w tekście artykułu występują inne terminy oznaczające jednostki podziału administracyjnego: obwód (odp. województwa), okręg, kraj (Kaukaski); ros. „ujezd” zostaje przetłumaczony jako „powiat” - A. S.

12 Pierwotnie zaufani urzędnicy państwowi, którzy wierność obowiązkom przysięgali poprzez gest pocałowania krzyża (stąd nazwa). W XIX wieku przyjęto określać tak szynkarzy - A. S. 
System więzienny ulega znaczącym zmianom w ostatnim trzydziestoleciu XVIII wieku, co jest związane przede wszystkim z wystąpieniami ludowymi i wzrostem opozycji wobec kręgów władzy w Imperium Rosyjskim. Kara więzienia staje się środkiem do walki przeciwko niezadowolonej szlachcie, czym uzasadnia się budowę twierdzy Pietropawłowskiej i Szlisselburskiej. W tym samym czasie pojawiają się domy poprawcze i domy pracy (art. 390-391 „Ordynacji o organizacji guberni” z 1775 r.) ${ }^{13}$. Poszerza się krąg przestępstw, których konsekwencją jest zesłanie, a takżejego geografia (Archangielsk, Chołmogory, Nowogród, Kazań, Symbirsk, Samara, Ufa, Astrachań, Perm itd.). Zesłanie spełnia, podobnie jak wcześniej, funkcję karną, ale w ten sposób dołącza do niej również rola kolonizatorska.

Ukazy $^{14}$ z 1703 i 1705 r. wprowadzają w Rosji katorgę ${ }^{15}$. Pierwotnie było to zesłanie na galery i katorgę na okrętach wiosłowych. Wyróżniano trzy rodzaje katorgi: na czas określony, dożywotnią i „do ukazu”. Kary tego typu były przewidziane dla osób, które popełniły szczególnie ciężkie przestępstwa (bunt, nieprzyzwoite słowa wobec reprezentanta najwyższej władzy, zabójstwo, oszustwo itp.).

Począwszy od końca XVIII w., górale z Północnego Kaukazu, którzy nawiązali stosunki z Imperium Rosyjskim, coraz częściej bywali uznawani za przestępców, w tym przestępców wojennych i zaczęto stosować wobec nich różne kary zgodne z prawem Imperium Rosyjskiego. Na przykład jednym z pierwszych znanych górali osadzonych w twierdzy był Czeczen szejk Mansur - przywódca góralskiego powstania, które objęło liczne obszary Północnego Kaukazu: Czeczenię, Kabardię, Kumycję, Dagestan, Czerkiesję (lata 1785-1791). W 1791 r., po zdobyciu twierdzy Anapa, do niewoli rosyjskiej trafiło ponad 13,5 tys. ludzi. W tym samym roku szejk i inni znaczący jeńcy, między innymi „generał pasza Mustafa, syn Batałpaszy", zostali przewiezieni do Sankt Petersburga. Chciała ich zobaczyć sama Katarzyna II. W Kalendarzu Kaukaskim z tej okazji można przeczytać: „1791 r. fanatyk Szych-Murza podburza Czeczenów. Wzięcie go do niewoli i zesłanie do Monasteru Sołowieckiego"16.

${ }^{13}$ Zob. Учреждения для управления губерний от 1775 г., ноября 7, [w:] http://constitution.garant.ru/history/act1600-1918/2350/\#sub_para_N_23. [dostęp: 8 V 2013 r.].

${ }^{14}$ Dekrety, edykty; w Rosji i ZSRR najważniejsze państwowe dokumenty wydawane przez najwyższe władze - A. S.

${ }^{15} \mathrm{Zob}$. Полное собрание законов Российской империи (ПСЗРИ), Собрание первое, t. IV, С.-Петербург 1830, ст. 1930, 1933, 2019, 2026.

${ }_{16}$ Кавказский календарь на 1848 г., Тифлис 1847, s. 10. 
Jak informuje P. G. Butkow, właśnie w tym klasztorze (więzieniu) szejk Mansur zmarł w wieku 31 lat ${ }^{17}$. Według innych źródeł w oczekiwaniu na swoją skruchę szejk był przetrzymywany w twierdzy Pietropawłowskiej. Zgodnie z reskryptem Katarzyny II z 15 października „Za podburzanie górskich ludów przeciwko Rosji i wyrządzenie dużych szkód Imperium" szejk Mansur został zamknięty w twierdzy Szlisselburskiej z utrzymaniem w wysokości 12 kopiejek na dobę. Pojedyncza cela, w której był przetrzymywany, znajdowała się w piwnicznym pomieszczeniu bez okien, po ścianach sączyła się lodowata woda. W takiej ciemności, milczeniu i wilgoci spędził on około trzech lat i umarł 13 kwietnia $1794 \mathrm{r}$. Szejk został pochowany na Preobrażeńskiej Górze bez jakiegokolwiek obrzędu ${ }^{18}$. Wiadomo, że do Aleksandra I w Sankt-Petersburgu przyjeżdżały delegacje górali z prośbą o wydanie im ciała szejka Mansura. Jednak miejsce jego pochówku pozostało nieznane, podobnie zresztą jak i wszystkich pozostałych więźniów twierdzy ${ }^{19}$.

Pod koniec XVIII w., w 1789 r., pojawiło się pierwsze więzienie na Północnym Kaukazie - w Stawropolu. Przez więzienie przechodzili etapowi aresztanci, którzy udawali się na katorgę lub zesłanie. Na początku XIX w. więzienie było już przepełnione aresztantami, co miało związek z rozpoczęciem działań wojennych na Kaukazie, wzrostem liczby jeńców i górali skazanych według prawa Imperium Rosyjskiego. W związku z tym, z inicjatywy dowódcy wojsk na Linii Kaukaskiej i naczelnika obwodu kaukaskiego P. H. Grabbego, rozpoczęto tam budowę nowego, bardziej przestronnego budynku. Drugie więzienie, „Błagodarnienskaja tiurma”, zostało wybudowane w 1893 r. we wsi Błagodarnoje w powiecie nowogrigoriewskim guberni stawropolskiej ${ }^{20}$.

W owym okresie na tym terenie powstają nowe twierdze, fortyfika- cje i posterunki, tworząc spójną Linię Kaukaską. Górale, którzy przyjęli rosyjskie poddaństwo, podlegali zwierzchnictwu naczelników linii kordonowej, dowódców twierdz i naczelników policyjnych. Według wyroków sądów wojskowych, które zostały utworzone w jednostkach wojskowych

${ }^{17}$ Zob. Россия и Кавказа сквозь два столетия, изд. сост. и подгот. Г. Г. Аисицына и Я. А. Гордон, Санкт Петербург 2001, s. 30.

${ }^{18}$ Zob. Ш. Ахмадов, Национальное освободительное движение в Чечне и на Северном Кавказе под предводительством имама Мансура в 1785-1791 г2., [w:] Чеченцьв: история и современность, ред. Ю. А. Айдаева, Москва 1996. s. 172.

19 Zob. А. Мусаев, Шейх Мансур, Москва 2007, s. 262-265.

${ }^{20}$ Zob. В. Пузиков, Тторьмы Ставропольской губернии, [w:] http://www.proza. ru/2011/12/27/623 [dostęp: 8 V 2013 r.]; М. К. Батчаева, Деятельность „Ставропольского nопечительного о тюрьмах комитета" в 40-70-х г2. XIX в., [w:] http://cyberleninka. $\mathrm{ru} /$ article/n/deyatelnost-stavropolskogo-popechitelnogo-o-tyurmah-komiteta-v-40-70h-gg-xix-veka [dostęp: 8 V 2013 r.]. 
armii rosyjskiej, ulokowanych w regionie, za szczególnie ciężkie przestępstwa górale byli sądzeni zgodnie $\mathrm{z}$ prawem wojskowym. Z reguły wobec skazanych stosowano takie kary, jak kara śmierci przez powieszenie, więzienie i zesłanie (do wewnętrznych guberni, na Syberię i do Azji Środkowej- do kopalni). Mężczyźni byli wcielani do wojska, najczęściej stacjonującego w Wlk. Ks. Finlandii ${ }^{21}$. Takie środki były z reguły podejmowane w stosunku do Czeczenów osadzonych w latach 20. XIX w. w twierdzy Grozny $^{22}$. Do chwili transportu na miejsce odbycia kary lub wykonania kary śmierci byli oni przetrzymywani w twierdzach i fortach, w których istniały areszty wojskowe. Dzieci straconych górali, wziętejako „amanaci" ${ }^{23}$, były kierowane do sierocińców wojennych i specjalnych jednostek wojskowych (na przykład do Dmitrijewskiego Wojskowego Sierocego Oddziału). Nietrudno sobie wyobrazić, jaki czekał ich los: utrata ojczyzny, rodziny, imienia, religii. W podobny sposób kształtował się los wielu małoletnich góralskich amanatów, zwłaszcza wtedy, gdy lokalne społeczności naruszały warunki umów z rosyjską administracją wojskową.

Wiek XIX charakteryzował się ciągłym reformowaniem systemu więziennego. $\mathrm{Na}$ ten proces składały się: budowa więziennych ostrogów (pierwsze dekady), więzień etapowych (lata 1819-1845, do chwili przyjęcia Kodeksu Kar Głównych i Poprawczych), reorganizacja ostrogów w więzienne zamki (lata 1845-1866, do wejścia w życie Kodeksu Karnego 1864 r. i reformy w latach 60. XIX w.). Jego zwieńczeniem było przygotowanie i przeprowadzenie reformy więziennictwa w $1879 \mathrm{r}$. Pod koniec XIX i na początku XX w. podjęta została próba przebudowy całego systemu penitencjarnego, dostosowania go do ogólnie przyjętych norm izolacji więźniów z włączeniem do niego funkcji poprawczo-wychowawczych ${ }^{24}$.

$\mathrm{W}$ pierwszych dekadach XIX $\mathrm{w}$. rozpoczyna się nowy etap budowy twierdz, fortyfikacji i posterunków na Północnym Kaukazie, spowodowany koniecznością umocnienia pozycji w regionie. Proces ten nasilał się szczególnie w okresie pełnienia obowiązków zarządcy ds. cywilnych na Kaukazie i w guberni astrachańskiej przez generała A. P. Jermołowa. Jak pisał D. I. Romanowskij, system działań skierowanych wobec górali ze strony Linii Kaukaskiej pod dowództwem A. P. Jermołowa polegał

${ }^{21}$ Zob. Российский Государственный Военно-Исторический Архив (РГВИА), фонд 13454, опис 2, дело 38, k. 45-45v.

${ }^{22}$ Ibidem, k. 2, 5, 13, 28.

${ }^{23}$ Arab. "amanat" - we wschodnich językach słowo oznaczające zakładnika - A. S.

${ }^{24}$ Zob. В. Тимофеев, Уголовно-исполнительная система России - иифры, факты u события, [w:] http://readr.ru/v-timofeev-ugolovno-ispolnitelnaya-sistema-rossii-cifrifakti-i-sobitiya.html?page=12\#ixzz2eSyjnbCf. [dostęp: 8 V 2013 r.]; А. П. Фадеев, Россия и Кавказ в первой трети ХІХ в., Москва 1960, s. 305. 
w głównej mierze na „trwałym umocnieniu się na ziemiach niepokornych społeczności za pomocą budowy wysuniętych fortyfikacji, dróg, wyrębu leśnych duktów, na działaniach ofensywnych przeciwko społecznościom, które z uporem sprzeciwiają się okazywaniu uległości, i na surowym traktowaniu ponownie ujarzmiony $\mathrm{ch}^{\prime 25}$.

Na przykład w 1817 r. zostaje wzniesiony fort Nazranowski, w 1818 r. - twierdza Grozny, w 1819 r. - twierdza Wniezapnaja, itd. Znajdowały się $\mathrm{w}$ nich administracyjne stanowiska dowodzenia, jednostki i areszty wojskowe. Przetrzymywano tutaj amanatów, osoby zatrzymane za naruszenie prawa, jeńców wojennych, $w$ tym kobiety i dzieci. Z reguły amanatami stawali się przedstawiciele najbardziej znaczących i szanowanych rodzin, co miało zapewnić przestrzeganie przez górali warunków porozumienia z administracją wojskową. Są tego liczne przykłady - w raporcie dowódcy wojsk trzeciej części Centrum Linii Kaukaskiej, generałamajora A. Z. Gorichwostowa, z 17 stycznia 1831 r. do dowódcy wojsk na Linii Kaukaskiej i Czarnomorzu, generała-lejtnanta A. A. Weljaminowa, informowano o znajdujących się w twierdzy Nalczyk amanatach wywodzących się z uprzywilejowanych stanów ludu karaczajewskiego. Zostali oni, wraz ze swoją służbą, pod nadzorem specjalnego oddziału dostarczeni do Stawropola. Amanat Tausułtan Krymszakałow i jego özden ${ }^{26}$ Abdrachman Bataszew zostali określeni jako „najsilniejsi z karaczajewskiego ludu" i dlatego, pod pozorem krnąbrności, polecono przetrzymać ich $w$ twierdzy na cały rok $^{27}$.

W listopadzie 1834 r. podpułkownik A. P. Pułło, dowodzący Linią Sunżeńska, informował w swoim raporcie, że w twierdzy Kizlar są zamknięte 144 kobiety, 11 małoletnich dzieci i pięcioro mężczyzn. Wszystkich wzięto do niewoli w czasie tłumienia "sprzeciwu” imama Kazimułły ${ }^{28}$. Z polecenia dowódcy wojsk Linii Kaukaskiej i Czarnomorza generała-lejtnanta A. A. Weljaminowa kobiety zostały oddane na służbę lokalnym kniaziom, oficerom i kozakom ${ }^{29}$.

W latach 20. i 30. XIX w. na Północnym Kaukazie rośnie w siłę ruch Murydów ${ }^{30}$, skierowany przeciwko umacnianiu rosyjskiej władzy w regionie, na jego czele stają imamowie Dagestanu i Czeczenii. W rezultacie

\footnotetext{
${ }_{25}^{2}$ Д. И. Романовский, Кавказ и Кавказская война, С.-Петербург 1860, s. 216.

${ }^{26}$ Termin odnoszący się do jednej $\mathrm{z}$ warstw w ludach tureckich, odpowiednik Szlachcica - A. S.

${ }_{27}^{2}$ РГВИА, фонд 13454, опис 8, дело 1, k. 1-1v.

${ }_{28}^{28}$ РВИА, фонд 13454, опис 2, дело 54, k. 8-8v, 9, 14, 15, 27-29, 41, 42, 45v-46.

${ }^{29}$ Ibidem, k. 5-5v.

${ }^{30}$ Persko-mahometańska nauka o charakterze religijnym i politycznym, stworzona w 1828 przez mułłę Mohameta w Dagestanie, fanatycznie wroga niewiernym. Jej zwolennicy zwali się Murydami - A. S.
} 
wzrasta liczba górali, w tym również uczestników działań wojennych, zesłanych z Kaukazu lub skazanych na różnej długości pobyt w rotach wojskowo-aresztanckich. Wiadomo, iż takie roty pojawiają się $\mathrm{w}$ Rosji po raz pierwszy w $1823 \mathrm{r}$. i początkowo były przeznaczone dla wojskowych, którzy popełnili przestępstwa, a później również dla osób cywilnych. Ukaz z 21 lutego 1834 r. ustanawia 43 aresztanckie roty w różnych regionach Imperium. Do 1837 r., czyli zaledwie po upływie trzech lat, ich liczba zwiększa się do 55. Na Kaukazie wojskowo-aresztanckie roty istniały w Stawropolu, Mozdoku, Kizlarze, Gelendżyku, Baku i Derbencie. Większość z nich została rozmieszczona $\mathrm{w}$ twierdzach na zachodniej i północno-zachodniej granicy oraz na Syberii ${ }^{31}$.

Początkowo do wojskowo-aresztanckich rot trafiali: przestępcy skazani na prace przy budowie twierdz, przedstawiciele niższych rang społecznych $w$ celu resocjalizacji, osoby skazane na prace przy budowie twierdz na czas określony, włóczędzy i przestępcy cywilni skierowani przez urzędy gubernialne. Do aresztanckich rot wysyłano również górali z Północnego Kaukazu, którzy trafili do niewoli rosyjskiej lub zostali oskarżeni o rozruchy, oraz dezerterów ze służby w rosyjskich wojskach. Do nich należeli również Polacy wydani z Turcji i Persji oraz górale kaukascy. Świadczą o tym przepisy prawa przyjmowane od lat 20. do 50. XIX w. (z 18 marca 1840 r., 17 marca 1843 r. itd.) ${ }^{32}$.

Góralscy jeńcy stawali przed możliwością przejścia na prawosławie. Jeśli odmawiali, wtedy po upływie terminu pobytu w rotach powracali do swojej ojczyzny. Ci, którzy przyjęli prawosławie i wykazali się jakimikolwiek zdolnościami, przystępowali do służby wojskowej, a po jej upływie osiedlali się w wewnętrznych guberniach Rosji. Pozostałych przekazywano resortowi cywilnemu, kierującemu ich do tak zwanych zakładów dobroczynnych. Tutaj również trafiali starzejący się i niezdolni do pracy góralscy jeńcy ${ }^{33}$.

Szczegóły pobytu aresztantów w rotach w latach 30. i 40. XIX w. sa, według W. N. Nikitina, okryte „nieprzeniknionym mrokiem”. Wiadomo jedynie, że panowało w nich „okrucieństwo i despotyzm”. „Wojskowoaresztanckie roty nie stały się ani miejscem do odbycia prawowitej kary za popełnione przestępstwa, ani gwarancją sprawiedliwości i kształtowania trudnych charakterów, były za to źródłem zysku i samowoli dla osób bezpośrednio i pośrednio nimi zarządzających, i, wreszcie, ogniskiem

${ }^{31}$ Zob. В. Н. Никитин, Быт военных арестантов в крепостях, С.-Петербург 1873, s. 3-4.

${ }^{32}$ Ibidem, s. 3-4.

${ }^{33}$ Ibidem, s. 14-15. 
wszelakiej ohydy"34 - jak pisze autor. W efekcie odnotowywano niemało przypadków ucieczek z rot.

Zgodnie z przepisami zatwierdzonymi przez Imperatora 27 lutego 1869 r. górale z rot wojskowo-aresztanckich, z wyjątkiem zesłanych „,z przyczyn politycznych", otrzymali prawo powrotu do ojczyzny, o ile nie popełnili nowych przestępstw i dostali zgodę władz kaukaskich ${ }^{35}$. Jednak taką możliwość bynajmniej nie otrzymali wszyscy. Zachowało się wiele dokumentów spraw górali-katorżników i zesłańców z prośbą o ułaskawienie $^{36}$.

Przepisy regulujące zesłanie górali kaukaskich do twierdz znajdujących się na zachodniej granicy (Bobrujsk, Brześć Litewski, Dyneburg (Dźwińsk) ${ }^{37}$ itd.), do wewnętrznych guberni, na Syberię i do Azji Średniej zaczęły kształtować się w pierwszych dekadach XIX w. ${ }^{38}$ Jak już było wspomniane, liczba góralskich zesłańców znacznie wzrosła w trakcie wojny kaukaskiej. Została wtedy w trybie administracyjnym wprowadzona procedura zsyłania "szkodliwych i przestępczych" górali kaukaskich. Z rozkazu Mikołaja I, wydanego we wrześniu 1848 r. namiestnikowi Kaukazu generałowi-feldmarszałkowi M. S. Woroncowowi, wolno było zsyłać mieszkańców kraju ${ }^{39}$, którzy nie pełnili służby państwowej, otrzymali Wojskowy Krzyż Zasługi w tymczasowej milicji, ale nie podlegali prawom urzędników państwowych lub przedstawicieli niższych rang w stanie spoczynku. Mogli oni być skazani bez sądu i śledztwa $\mathrm{w}$ trybie administracyjnym na zesłanie do wewnętrznych guberni Rosji pod nadzór policji, przy czym niezależnie od tego, czy posiadali rangi lub odznaczenia wojskowe ${ }^{40}$ za wcześniejsze zasługi. Takie środki mogły być podjęte tylko $\mathrm{z}$ wyroku sądu, zatwierdzonego przez samego Imperatora. Jako przykład może posłużyć sprawa Czeczena Maczyka Turczyjewa zesłanego „,w trybie administracyjnym na Syberię, na przymusowe osiedlenie, bezterminowo, za nieprawomyślne czyny i złe zachowanie i za podburzanie innych" w czasie przejazdu namiestnika. W listopadzie 1859 r., głównodowodzący Kaukaską Armią, ks. A. I. Bariatyński, skierował prośbę do Imperatora Aleksandra II o zatwierdzenie tego zarządzenia ${ }^{41}$.

\footnotetext{
${ }^{34}$ Ibidem, s. 16.

${ }^{35}$ РГВИА, фонд 330, опис 14, дело 250, k. 2-3v.

${ }^{36}$ РГВИА, фонд 1, опис 1, дело 25284; фонд 330, опис 3, дело 553; опис 6, дела 672, 708; опис 16, дело 775; опис 19, дело 1095; фонд 1308, опис 1, дела 16810, 19243, 19377.

${ }^{37}$ Daugavpils na Łotwie - A. S.

${ }^{38}$ РГВИА, фонд 13454, опис 2, дело 54, k. 28v, 41, 42, 45-46.

${ }^{39} \mathrm{~W}$ znaczeniu: jednostka podziału administracyjnego państwa - A. S.

${ }^{40}$ РГВИА, фонд 1, опис 1, дело 25284, k. 1-2v.

${ }^{41}$ Ibidem, k. 1-1v.
} 
Zgoda Imperatora była wymagana również w przypadkach powrotu z zesłania górali kaukaskich, którzy wywarli pozytywne wrażenie w miejscu odbywania kary. Przedterminowe zwolnienie przebiegało według ściśle określonych zasad. W czasie działań wojennych z podobną prośbą zwracało się dowództwo Armii Kaukaskiej i lokalni naczelnicy wojskowi. W taki sposób w 1862 r. wrócił do ojczyzny Czeczen Jusup Mazijew, zesłany w $1857 \mathrm{r}$. na osiem lat do twierdzy Bobrujsk. Prośbę o ułaskawienie syna wniósł jego ojciec. Począwszy od oficjalnej prośby dowódcy wojska obwodu tereckiego, ks. Światopołk-Mirskiego, i pozytywnej odpowiedzi komendanta twierdzy w Bobrujsku, dotyczącej zesłańca, dowództwo Kaukaskiej Armii zwróciło się do ministra wojny z prośbą o wszczęcie przed Imperatorem sprawy dotyczącej zwolnienia $\mathrm{z}$ aresztanckich rot J. Mazijewa i odesłania go do ojczyzny. Sprawa została rozpatrzona pozytywnie ${ }^{42}$.

Rząd określił normy wydatków związanych z wysyłaniem przestępców do miejsca przeznaczenia (do Wołogdy, Permu i Tobolska), które były inne dla prostych górali i przedstawicieli uprzywilejowanych klas społecznych. W związku z tą kwestią 27 sierpnia 1852 r. Aleksander II zatwierdził specjalny regulamin ${ }^{43}$. Górale byli nie tylko zsyłani, ale i wcielani do wojska ${ }^{44}$.

Po zakończeniu działań wojennych na Północnym Kaukazie regularnie dochodziło tam do wystapień społecznych, $\mathrm{w}$ których brali udział oficerowie i milicjanci wywodzący się z ludów górskich. Na przykład w 1858 r. doszło do powstania Inguszów niezadowolonych z przesiedlenia na równiny, w którym uczestniczyli również oficerowie. Większa część uczestników, wśród których wielu miało tytuły i odznaczenia wojskowe za zasługi wobec rosyjskiego rządu, została poddana karze szpicruty i pozbawiona wszelkich praw stanowych, rang i odznaczeń wojskowych, następnie zesłana na Syberię na katorgę - do kopalń ( $w$ tym również bezterminowo) i do prac w fabrykach ${ }^{45}$.

Biorąc powyższe pod uwagę, 18 czerwca 1866 r. resortowi wojennemu zostaje ogłoszony regulamin, zatwierdzony przez Aleksandra II, o administracyjnym trybie zsyłania "szkodliwych i przestępczych" górali kaukaskich, którzy posiadają odznaczenia wojskowe i medale. Istniejące prawa uzupełniono o przepis mówiący o tym, iż górale wysyłani z kraju w trybie administracyjnym za przestępstwa kryminalne i „haniebne" czy-

${ }^{42}$ РГВИА, фонд 330, опис 6, дело 672, k. 1-1v.

${ }^{43}$ ПСЗРИ, Собрание второе, t. 27, С.-Петербург 1855, ст. 26554, s. 540.

${ }_{44}$ РГВИА, фонд 13454, опис 2, дело 495, k. 1-12.

${ }^{45}$ Г. К. Мартиросиан, История Ингушии. Материаль, [w:] Ингушский НИИ краеведения, Орджоникидзе 1933, s. 70-71. 
ny bez sądu zostają pozbawieni wszelkich odznaczeń po każdorazowym uzyskaniu na to zgody Imperatora. Zaś górale, którzy nie zostali zesłani za ciężkie przestępstwa i „haniebne” czyny, a jedynie jako ludzie szkodliwi w kraju, mogli zachować swoje odznaczenia ${ }^{46}$.

W drugiej połowie XIX i początkach XX w. kontrola policyjna i administracyjna uległy zaostrzeniu, szczególnie po próbie zamachu na Aleksandra II 4 kwietnia 1866 r. 9 września 1867 r. zatwierdzono Regulamin Korpusu Żandarmów, który obejmował również okręg kaukaski ${ }^{47}$. Uchwalono, iż administracja terytorialna Żandarmerii nie będzie podlegała lokalnym władzom cywilnym. W okólniku Ministerstwa Spraw Wewnętrznych z 12 października 1866 r. zakładano wyłączenie z kompetencji organów administracyjnych na Kaukazie nadzoru policyjnego i przekazanie go urzędnikom Żandarmerii ${ }^{48}$. Jednak namiestnik Kaukazu, wielki książę Michaił Nikołajewicz, wyraził zgodę jedynie na zastosowanie specjalnej Instrukcji. Z czasem polecono rozpowszechnić ją we wszystkich jednostkach Żandarmerii w wewnętrznych guberniach Impe- rium Rosyjskiego ${ }^{49}$.

Zgodnie ze wskazaniem w Notatce Wyjaśniającej do „Projektu przekształceń wojskowo-ludowego zarządu na Kaukazie” (1885 r.) głównodowodzący otrzymywał nie tylko prawo do osadzania w więzieniu i administracyjnego zsyłania górali na czas określony bądź na zawsze na Syberię i do wewnętrznych guberni. Mógł on również zarządzić wydalenie do wybranego w tym celu miejsca na obszarze Kraju Kaukaskiego na okres nie dłuższy niż pięć lat. Kara więzienia i zesłanie w trybie administracyjnym na czas określony lub dożywotnio były stosowane:

1) za przestępstwa dowiedzione przez zwyczajowe sądy ustne $e^{50}$ górali kaukaskich, które zgodnie z prawem nie mogły być karane według adatu $^{51}$ (zabójstwo z premedytacją i okaleczenie, krwawa zemsta, rozbój, grabież, itp.);

2) za kradzież domowego bydła, za nieposłuszeństwo i niesubordynację wobec zarządzeń władz, za złe zachowanie, w przypadku

\footnotetext{
${ }^{46}$ ПСЗРИ, Собрание второе, t. 36, Санкт Петербург 1863, ст. 57125, s. 975.

47 Р. С. Мулукаев, А. Я. Малыгин, А. Е. Епифанов, История отечественных органов внутренних дел: учебник для вузов, Москва 2005, s. 50.

${ }^{48}$ Н. П. Ерошкин, История государственных учреждений дореволюияионной России, Москва 1997, s. 5. k. 45 .

${ }^{49}$ Государственный Архив Российской Федерации, фонд 110, опис 3, дело 1108,

${ }^{50}$ Tradycyjne dla danej społeczności sądy, w których postępowanie toczyło się $\mathrm{w}$ formie ustnej; w ten sposób podawano również wyroki - A. S.

${ }^{51}$ Adaty - muzułmańskie prawa zwyczajowe - A. S.
} 
gdy wszystkie środki zastosowane do poprawy winnego okazały się nieskuteczne;

3) ze względów politycznych.

Ostatni punkt według autorów Notatki nie wymagał komentarza. Wszystkie znaczące wydarzenia w świecie muzułmańskim, zwłaszcza w Turcji, znajdowały mniej lub bardziej życzliwy odzew wśród kaukaskich muzułmanów, dlatego też w takich przypadkach tylko czasowe wydalenie z regionu "gorących głów" mogło powstrzymać rozpoczynające się wrzenie ${ }^{52}$.

Za popełnienie ciężkich przestępstw kryminalnych wprowadzono następujące rodzaje kar: areszt, zesłanie do wewnętrznych guberni, zesłanie na Syberię na czas określony lub dożywotnio. Za lżejsze przestępstwa: grzywna w wysokości do 100 rubli, zesłanie w granicach guberni (do innych okręgów). Sankcje administracyjne przewidywały: karę więzienia, zesłanie do wewnętrznych guberni lub na Syberię. Druga kategoria, zesłańcy ",administracyjni”, składała się z górali kaukaskich zesłanych na podstawie odrębnych przepisów funkcjonujących $\mathrm{w}$ obwodzie tereckim. Zgodnie z tymi przepisami podejrzenie o kradzież koni lub bydła podlegało administracyjnemu zesłaniu na Wschodnią Syberię - według rozporządzenia władz lokalnych. Zesłańcy „administracyjni” nie różnili się statusem od tych, którzy zostali skazani przez sąd i w praktyce tworzyli jednolitą grupe $\varepsilon^{53}$.

Tworząc policyjne oraz inne organy ścigania, kaukaska administracja kierowała się przepisami prawnymi z dnia 25 grudnia 1862 r. „O organizacji policji w miastach i powiatach” i z 8 czerwca 1865 r. „O gubernialnych urzędach Ministerstwa Spraw Wewnętrznych" z zachowaniem niektórych wyjątków. Pod koniec XIX w. zostaje przyjęty „Regulamin Zarządzania Krajem Kaukaskim" (1884 r.), który nadawał naczelnikom powiatowym (okręgowym) „wszelkie prawa i obowiązki, które zgodnie $\mathrm{z}$ dekretami na mocy ustawy przynależą isprawnikom ${ }^{54}$ i powiatowej administracji policyjnej" ${ }^{\prime 5}$. Miejskie Urzędy Policyjne tworzono na podstawie funkcjonujących w Imperium dekretów na mocy ustawy. W swojej pracy policjanci i naczelnicy powiatowi (okręgowi) zobowiązywali się do przestrzegania przepisów regulujących pracę policji, ujętych w „Ogólnej Organizacji Gubernialnej"56.

\footnotetext{
52 РГВИА, фонд 400, опис 1, дело 950, k. 10-10v.

${ }^{53}$ Ibidem.

${ }^{54}$ Hist. isprawnik - naczelnik policji powiatowej, naczelnik powiatu.

55 Архив Внешней Политики Российской Империи, Персидский Стол, фонд 144, опис 488, 1884 год, дело 417, k. 28v.

${ }^{56}$ Ibidem, k. 28v-29.
} 
Zgodnie z „Organizacją Zarządu Obwodu Kubańskiego i Tereckiego, i Okręgu Czarnomorskiego" z 21 marca 1888 r., okręgi podlegały zarządowi naczelników, ci z kolei naczelnikowi obwodu i obwodowej administracji. Podlegali oni prawom i obowiązkom przewidzianym przez ogólny regulamin funkcjonujący w Imperium Rosyjskim dla isprawników i powiatowej administracji policyjnej. Podporządkowani im naczelnicy rejonowi zostali zrównani swoim statusem z przystawami stanowymi ${ }^{57}$ i podlegali odrębnym instrukcjom, które zatwierdzał dowódca wojsk Kaukaskiego Okręgu Wojskowego ${ }^{58}$. Naczelnicy miejskich okręgów pełnili funkcje administracyjne i policyjne. W okręgach działały posterunki milicyjne, utrzymywane ze środków ludności górskiej, które były podporządkowane naczelnikom obwodów i okręgów ${ }^{59}$.

W celu zabezpieczenia "porządku społecznego i spokoju” naczelnik okręgu miał prawo za administracyjne wykroczenia stosować wobec prostych górali kaukaskich areszt do siedmiu dni lub karę pieniężną w wysokości do 15 rubli. Informacje o łamaniu prawa przez osoby uprzywilejowane lub górali, którzy posiadali stopnie wojskowe i cywilne, ale nie pełnili służby państwowej, przekazywano naczelnikowi obwodu. Naczelnik rejonowy, następna w kolejności rang osoba urzędowa, mógł poddawać prostych górali karze aresztu do trzech dni i nakładać grzywny w wysokości do pięciu rubli. O administracyjnych wykroczeniach osób $\mathrm{z}$ drugiej grupy informował naczelnika okręgu ${ }^{60}$.

Policyjne władze okręgowe wraz z Żandarmerią czyniły wszystko, by ograniczyć swobodę poruszania się górali kaukaskich, zlikwidować wszelkie objawy niezadowolenia oraz uwolnić kraj od „niebezpiecznych elementów". Korzystając z przynależnych jej praw, miejscowa administracja organizowała masowe, grupowe i pojedyncze wysyłki górali kaukaskich na określony czas do aresztanckich rot i więzień.

Podejmowane przez lokalną administrację środki nadzoru nad ludnością $\mathrm{w}$ pewnych okresach kończyły się pełnym powodzeniem. Dla przykładu: w jednym z dokumentów odnotowywano, iż począwszy od 1878 r. „pokojowy bieg spraw na Kaukazie ani razu nie został naruszony i lokalna administracja mogła skupić się na kwestii materialnego rozwoju $\mathrm{kraju}^{\prime \prime 61}$. Podobny wniosek, jak się wydaje, odpowiadał ogólnej sytuacji $\mathrm{w}$ regionie, ale stabilizacja pokojowa nie została osiągnięta w Czeczenii.

${ }^{57}$ Ros. - stanowoj pristaw - odpowiednik komisarza w policji w Rosji w latach 1837-1917 - A. S.

${ }^{58}$ ПСЗРИ, Собрание третье, t. 8, С.-Петербург 1888, ст. 5077, s. 101, 104, 105.

${ }^{59}$ Ibidem .

${ }^{60}$ Ibidem.

${ }^{61}$ РГВИА, фонд 400, опис 1, дело 723, k. 22. 
Rzecz w tym, iż w drugiej połowie XIX w. przez cały czas odnotowywano tu wystąpienia przeciwko władzy.

W związku z przyjęciem Kodeksu Kar Głównych i Poprawczych (1845 r.), który przewidywał za konkretne naruszenie prawa nie tylko zesłanie, ale też skierowanie do poprawczych aresztanckich rot, karę więzienia, osadzenie $\mathrm{w}$ twierdzy, domu poprawczym lub domu pracy, szczególnie aktualna stała się kwestia systemu więziennego. W latach 60. XIX wieku Mikołaj I podjął próby przeprowadzenia reformy więziennictwa, nie dały one jednak istotnych rezultatów. System więzienny w Rosji ostatecznie ukształtował się dopiero pod koniec lat 70. XIX w. 11 grudnia 1879 r. Rosyjska Rada Państwowa przyjęła Ustawę „O ogólnych zasadach przekształcenia systemu więziennego". Zgodnie z jej treścią zaczęły powstawać Regionalne Zarządy Więziennictwa, podporządkowane Głównemu Zarządowi Więziennictwa Ministerstwa Spraw Wewnętrznych. Lokalnie zarząd administracyjny nad więzieniami sprawowały władze gubernialne, obwodowe i miejskie.

Do początku XX wieku w Rosji istniało 895 więzień. W dniu 1 stycznia 1900 r. znajdowało się w nich 90141 więźniów ${ }^{62}$. Miejsca dozorowanego odbywania kar dzieliły się na: a) pomieszczenia dla osób znajdujących się pod aresztem; b) aresztanckie pomieszczenia przy policji; c) więzienia (gubernialne, obwodowe i powiatowe więzienia-zamki); d) poprawcze roty aresztanckie; e) więzienia służące do przetrzymywania przestępców skazanych na ciężkie prace na katordze; f) więzienia etapowe ${ }^{63}$.

W obwodzie tereckim pierwsze specjalne instytucje więzienne i więzienna policja pojawily się $\mathrm{w}$ drugiej połowie lat 60. XIX w. W $1876 \mathrm{r}$. w obwodzie tereckim istniało sześć więzień. Naczelnik obwodu w Sprawozdaniu o Stanie Guberni za 1910 r. pisał, że dla aresztantów, którzy odbywają orzeczoną przez sąd karę, jak i dla tych, którzy znajdują się $\mathrm{w}$ areszcie prewencyjnym na czas czynności sądowych i śledztwa, w obwodzie tereckim działa 11 więzień. Liczby aresztantów w miejscach odbywania kar ukazuje tabela $1^{64}$.

W obwodzie funkcjonował Władykaukaski Komitet Nadzoru nad Więzieniami, na czele którego stał naczelnik obwodu. Podobne komitety znajdowały się w Mozdoku, Chasawjurcie, Wiedeno i Szatoju ${ }^{65}$.

\footnotetext{
${ }^{62}$ М. Н. Гарнет, История ц̧арской тюрьмиь, t. 3, 1870-1900, Москва 1961, s. 380.

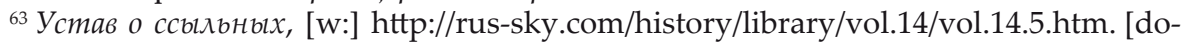
stęp: 8 V 2013 r.]

${ }^{64}$ Всеподданнейший отчет Начальника Терской области и наказного атамана Терского казачьего войска за 1910 год, Владикавказ 1911, s. 65.

65 3. Х. Ибрагимова, Чеченский народ в Российской империи: адаптациионный период, Москва 2006, s. 290.
} 
Po zabójstwie Aleksandra II (1 marca 1881 r.) w całym Imperium 14 sierpnia 1881 r. zostaje wprowadzony stan podwyższonej ochrony bezpieczeństwa państwa ${ }^{66}$. Odbiło się to na okręgach Kaukazu. W celu osiągnięcia większej skuteczności połączono tu władzę policyjną i wojskową. W ten sposób 16 kwietnia 1888 r. zarząd administracyjny i policyjny nad obwodem tereckim, z wyłączeniem osobnego Korpusu Żandarmów, zostaje przekazany z Ministerstwa Spraw Wewnętrznych do Ministerstwa Wojny. Oznacza to uprawomocnienie reżimu wojskowo-policyjnego. Urzędnicy lokalnej administracji dostają szerokie uprawnienia ${ }^{67}$. Naczelnik obwodu tereckiego wydaje cały szereg rozkazów, mających zapewnić porządek społeczny, które w rzeczywistości wprowadzają nowe ograniczenia w życiu górali kaukaskich. Na przykład zostają zatwierdzone

"Przepisy o paszportach dla mieszkańców obwodu tereckiego" (rozkaz dla obwodu z 15 marca 1891 г. № 37). Ustalają one zakaz swobodnego osiedlania się mieszkańców regionu, zakaz bezprawnego zamieszkiwania w miastach, na chutorach (znajdujących się zarówno na ziemiach stanicy, jak i gmin wiejskich) oraz na działkach prywatnych właścicieli bez odpowiedniego oficjalnego zezwolenia ${ }^{68}$.

3 września 1893 r. Dowodzący Kaukaskim Okręgiem Wojskowym zezwala na wnoszenie do sądu wojskowego spraw o rozboje, zabójstwa, grabieże, podpalenia i zbrojne wystąpienie przeciwko władzy, jeżeli te przestępstwa zostały popełnione przez górali Kraju Kaukaskiego ${ }^{69}$.

19 listopada 1893 r. rozszerzono na obwód terecki działanie Ustawy „O zwiększeniu odpowiedzialności karnej za kradzież koni i bydła domowego". Winni świadomego kupna bądź sprzedaży uprowadzonego bydła byli pozbawiani wszelkich praw i przywilejów, a następnie trafiali do poprawczych rot aresztanckich na okres uzależniony od ciężaru popełnionego przestępstwa ${ }^{70}$. W Sprawozdaniu o Stanie Guberni z 1894 r. naczelnik obwodu tereckiego wskazuje, iż ze wszystkich wyszczególnionych przepisów prawa ten ostatni zwłaszcza dotknął górali kaukaskich. Na mocy tego prawa w samym 1894 r. karze zesłania podlegało 112 osób, z których połowa pochodziła z okręgu groźnieńskiego - 54 osoby ${ }^{71}$.

${ }^{66}$ Ю. П. Титов, ор.cit., s. 264-265.

67 Э. Д. Мужухоева, Административная политика цุаризма в Чечено-Ингушетии во второй половине XIX-нач. ХХ в., Москва 1989, s. 123, maszynopis pracy kandydackiej przechowywany w Российской Государственной Библиотеке.

${ }_{68}$ Правила о паспортах для туземиев Терской области, [w:] Терский календарь на 1892 год, ks. 1, Владикавказ 1891, s. 134-136.

${ }^{69}$ Всеподданнейший отчет начальника Терской области и наказного атамана Терского казачьего войска за 1894 год, Владикавказ 1895, s. 63.

70 „Терские Ведомости” 1909, nr 90, s. 1.

${ }^{71}$ Всеподданнейший отчет начальника Терской области...за 1894 год, s. 64. 
Tabela 1. Liczba osadzonych w więzieniach w obwodzie tereckim w latach 1910-1011

\begin{tabular}{|l|c|r|r|c|}
\hline \multirow{2}{*}{ Więzienie } & \multirow{2}{*}{$\begin{array}{c}\text { Stan na } \\
\text { 1 stycznia 1910 r. }\end{array}$} & \multicolumn{2}{|c|}{ W trakcie 1910 г. } & \multicolumn{1}{c|}{$\begin{array}{c}\text { Stan do } \\
\text { Groźnieńskie }\end{array}$} \\
\cline { 3 - 4 } & 280 & 1283 & 1280 & 283 \\
\hline Nazrańskie & 76 & 491 & 514 & 53 \\
\hline Wiedeńskie ${ }^{19}$ & 59 & 205 & 226 & 38 \\
\hline Szatojewskie & 18 & 142 & 126 & 34 \\
\hline Władykaukaskie & 821 & 1867 & 1909 & 779 \\
\hline Chasawjurtowskie & 192 & 885 & 901 & 176 \\
\hline
\end{tabular}

W 1894 r., w związku z wielką liczbą kradzieży zwierząt hodowlanych $^{72}$, zostaje przyjęty Regulamin „O rozszerzeniu na obwody kubański i terecki ustanowionych dla guberni astrachańskiej i stawropolskiej oraz dla okręgu salskiego należącego do obwodu Wojska Dońskiego przepisów o administracyjnym zsyłaniu na Wschodnią Syberię osób oskarżonych lub podejrzanych o kradzież koni i bydła"73.

Zaostrzeniu ulega egzekwowanie prawa zakazującego noszenie przez górali broni, która od czasów wojny kaukaskiej nagromadziła się tu w wielkiej ilości i komplikowała sytuację w regionie. Ścisły nadzór nad wykonywaniem przepisów dotyczących noszenia broni przez górali, które zostały wprowadzone przez głównodowodzącego służby cywilnej na Kaukazie A. M. Dondukowa-Korsakowa, był realizowany od 1882 r. W samym 1884 r. w obwodzie tereckim odebrano 2833 różnych sztuk broni, również z wyroków góralskich zwyczajowych sądów ustnych. W tym samym roku zostają wprowadzone nowe zarządzenia dotyczące sprzedaży, posiadania i noszenia bojowej broni palnej ${ }^{74}$. Zostają też ustalone sankcje wobec osób, które albo nie oddały broni zgodnie z wymogami władzy, albo stawiły opór przy próbie odebrania. W pierwszym przypadku były to grzywny w wysokości 15 rubli, które nakładano nie tylko na winną

72 Zbiorcza nazwa dwóch odrębnych terminów zawartych $\mathrm{w}$ tekście oryginału. W rosyjskiej terminologii rozróżnia się dosł. „duże bydło rogate” (krupnyj rogatyj skot), odpowiednik rogacizny, i „drobne bydło rogate” (miełkij rogatyj skot) - owce, kozy.

73 ПСЗРИ, Собрание третье, t. 13, С.-Петербург 1897, ст. 10065, s. 607; Терский календарь на 1895 год, Владикавказ 1894, s. 156-157.

${ }^{74}$ Всеподданнейший отчет начальника Терской области... 1894 год, s. 65. 
osobę, ale również na każdego spokrewnionego z nim mężczyznę, który mieszkał w tej samej osadzie ${ }^{75}$.

Ludność górska zostaje pouczona o konieczności oddania broni palnej pod groźbą kary, obejmującej nawet zesłanie razem z rodzinami na Syberię i do Azji Średniej. Władze obwodowe wydają z tego powodu całą serię wyroków. Uściślając, w 1891 r. zostają wydane „Przepisy o noszeniu broni przez mieszkańców w obwodzie tereckim” i „Przepisy dotyczące sprzedaży, posiadania i noszenia bojowej broni palnej w Kraju Kaukaskim"76. Od 1893 r. funkcjonuje rozkaz „O pozbawieniu niektórych mieszkańców prawa do noszenia broni"77. 24 listopada 1905 r. nabierają mocy prawnej „Powszechne zasady dotyczące posługiwania się bronią oparte na zatwierdzonym przez Imperatora 24 listopada 1905 r. memoriale Rady Ministrów"78.

Naczelnicy obwodu tereckiego regularnie wydawali rozkazy o pozbawieniu całych osad prawa do noszenia broni. Dla przykładu, w 1891 r została rozbrojona wieś Surchochi, w 1893 r. - chutory Gałaszewskie i wieś Bazorkino w rejonie sunżeńskim, wieś Staryj Jurt okręgu groźnieńskiego; mieszkańców wymienionych osad na zawsze pozbawiono prawa do noszenia broni ${ }^{79}$. Często egzekucja prawa kończyła się stawieniem oporu wobec policjantów i urzędników wojskowych, co z kolei skutkowało aresztem, karą więzienia, zesłaniem.

Reżim policyjny nasilił się szczególnie $\mathrm{w}$ latach pierwszej rewolucji rosyjskiej 1905-1907. Sytuacja w poszczególnych okręgach obwodu tereckiego, zwłaszcza w takich centrach przemysłowych, jak Grozny, charakteryzowała się krańcowym napięciem i pozostawała pod nieustanną kontrolą agentury i policyjnych urzędników. Przewrót państwowy w dniu 3 czerwca 1907 r. oznaczał koniec pierwszej rewolucji rosyjskiej i początek reakcji. Rząd Carski i jego kaukaska administracja podejmują cały szereg środków do stłumienia ruchu rewolucyjnego. $Z$ rozkazu namiestnika Kaukazu z 7 czerwca 1907 r. w kraju zostaje wprowadzony stan wyjątkowy. W celu pacyfikacji ustanowiono tymczasowe stanowiska generałówgubernatorów, formowano specjalne oddziały karne, stosowano też inne nadzwyczajne środki.

15 czerwca 1907 r. tymczasowy generał-gubernator obwodu tereckiego ogłosił na jego terytorium stan wojenny. 22 czerwca 1909 r. stan

75 Э. А. Мужухоева, ор.cit., s. 123-124.

${ }_{76}$ Терский календарь на 1892 год, ks. 1, Владикавказ 1891, s. 131-133.

${ }_{77}^{7 е р с к и и ̆ ~ к а л е н д а р ь ~ н а ~} 1894$ год, ks. 1, Владикавказ 1893, s. 64.

78 „Терские Ведомости” 1906, nr 23, s. 1.

${ }^{79}$ Всеподаннейший отчет начальника Терской области и наказного атамана Терского казачьего войска за 1893 год, Владикавказ 1894, s. 65-66. 
wojenny zostaje zniesiony, zaś na jego miejsce na mocy Ukazu Imperatora skierowanego do Rządzącego Senatu z dnia 17 czerwca 1909 r. został wprowadzony stan podwyższonej ochrony. W konsekwencji wydawano obowiązujące na terytorium obwodu tereckiego uchwały. Według jednej z nich, „O pilnowaniu porządku wewnętrznego w domach", właściciele "dóbr nieruchomych obwodu tereckiego" lub odpowiedzialni zarządcy byli zobowiązani do bezzwłocznego zawiadamiania lokalnych rejonowych Urzędów Policyjnych o wszelkich nadzwyczajnych zdarzeniach, o podejrzanych spotkaniach itp. Dla osób, które naruszyły zaprowadzony ład, wprowadzono kary grzywny w wysokości do 500 rubli lub areszt do trzech miesięcy ${ }^{80}$.

Samowola administracyjna i policyjna, która zapanowała w okręgach górskich tuż po zakończeniu wojny kaukaskiej, nasilała się za każdym razem po masowych wystąpieniach, które powtarzały się tu regularnie. Dużą grupę aresztantów i zesłanych kaukaskich górali stanowili uczestnicy powstań od lat 50. do 80. XIX w. Jak już było wspomniane, w $1858 \mathrm{r}$. doszło do powstania w Inguszetii. Wielu jego aktywnych uczestników spotkały za to ciężkie kary. Na przykład 33 uczestników powstania, nie wyłączając osób w starszym wieku, skazano na kary cielesne, pozbawiono wszelkich praw stanowych i zesłano na Syberię na katorgę; 5 osób bezterminowo do kopalni, 28 na osiem lat do pracy w fabrykach itd. ${ }^{81} \mathrm{~W}$ istocie już od zakończenia wojny na Wschodnim Kaukazie, w maju 1860 r., rozpoczęły się zamieszki wśród Czeczenów okręgu arguńskiego pod przewodnictwem Umy Dujewa i Atabi Atajewa ${ }^{82}$. W latach 1860-1861 wybuchło powstanie w okręgu iczkeryjskim pod dowództwem Bajsangura (byłego naiba ${ }^{83}$ Szamali, który nie poddał się władzom rosyjskim) i Sułtan-Murada Bienojewskich $^{84}$.

W latach 50. i 60. w Czeczenii pod przywództwem Kunta-Hadżiego Kiszijewa rodzi się nowy tarikat ${ }^{85}$ - kadirijja, którego wyznawcy

\footnotetext{
80 „Терские Ведомости” 1909, nr 88, s. 1.

81 А. И. Иванов, Национально-освободительные движения в Чечне и Дагестане в 60-70x XIX в., „Исторические записки” 1941, nr 12, s. 181; Г. К. Мартиросиан, op.cit., s. 70-71.

${ }^{82}$ А. И. Иванов, Восстание в Чечне в 1877 2., „Вопросы Истории” 1940, nr 12, s. 280-294; С. А. А. Исаев, Присоединение Чечни к России. Аграрная политика изаризма и народные движения в крае в ХІХ в., Москва 1998, s. 220-234, maszynopis pracy kandydackiej przechowywany w Российской Государственной Библиотеке.

${ }_{83} \mathrm{~W}$ dawnych państwach muzułmańskich stanowisko m.in. zastępcy lub pomocnika naczelnika bądź osoby duchowej. Muzułmańska metoda poznania mistycznej prawdy, później - grupy wyznawców skupionych wokół przywódców duchowych - A. S.

${ }^{84}$ Zob. C. A. A. Исаев, op.cit., s. 235-253.

${ }^{85}$ Muzułmańska metoda poznania mistycznej prawdy, później - grupy wyznawców skupionych wokół przywódców duchowych - A. S.
} 
początkowo byli prześladowani przez imama Szamali, a następnie przez lokalną administrację. W latach 1863-1864 aktywizuje się ruch „zikrystów" ${ }^{\prime \prime 6}$ w Iczkerii i w styczniu 1864 r. rozpoczyna się powstanie, którego centrum stanowi osada Szali. Kunta-Hadżi został pojmany i 3 lutego $1865 \mathrm{r}$. rozpoczął drogę na bezterminowe zesłanie pod jawnym nadzorem do miasta Ustiużna w guberni nowogrodzkiej. Umarł z głodu i wycieńczenia

19 maja 1867 r. Jego miejsce pobytu, fakt śmierci i miejsce pochówku były zastrzeżone jako tajne. Czeczeńscy naibowie i starszyzna zostali wezwani do twierdzy Grozny, gdzie 26 stycznia 1864 r. naczelnik okręgu groźnieńskiego M. T. Łoris-Mielikow zażądał od nich wydania zikrystów do 1 lutego i zakazania zikru. W konsekwencji zostało aresztowanych osiem osób, z których siedem ukarano zesłaniem na prace przy budowie twierdz na okres czterech-pięciu lat w następujące miejsca: Kronsztad, Suomenlinna, Wyborg, Dynemunt, Dyneburg, Bobrujsk, Brześć Litewski, Bendery, a następnie na przymusowe osiedlenie na Syberii. Ich rodziny zostały skierowane do Jekaterynogrodu. Spośród zesłanych zikrystów sześciu nie zdołało dotrzeć na miejsce przeznaczenia. Ich los jest nieznany. Troje zmarło ${ }^{87}$.

W maju 1865 r. próbował wzniecić powstanie uczeń Kunta-Hadżiego, Taza Esmurzijew ${ }^{88}$. Rewolucyjne wystąpienie miało się rozpocząć 24 maja niedaleko wsi Characzoj. Wysłany przez naczelnika obwodu wojskowy oddział aresztował Tazę i jego 17 pomocników. Wojskowy sąd polowy skazał ich na karę śmierci, ale później została ona zamieniona na 12 lat katorgi. Wspierająca zikrystów wieś Elistanży została przesiedlona do naibstwa nadterecznego ${ }^{89}$, a wieś Characzoj ukarano grzywną w wysokości 1000 rubli. $W$ następnym roku w grudniu został aresztowany jeszcze jeden zwolennik Kunta-Hadżiego - Abdurachman Ibrachimow, głoszący zikryzm w południowo-wschodniej Czeczenii ${ }^{90}$.

Największe powstanie ostatniego dwudziestopięciolecia XIX wieku miało miejsce w Czeczenii pod wodzą Alibeka-Hadżiego Ałdamowa i Uma-Hadżiego Dujewa, skąd rozszerzyło się na sąsiedni Dagestan ${ }^{91}$. Po jego stłumieniu w 1877 r. w Groznym odbył się wojskowy sąd polowy

\footnotetext{
${ }^{86}$ Arab. zikr - rozmyślanie o Allachu; zikryści - zwolennicy szejka Kunta-Chadżiego Kiszijewa - A. S..

87 3. Х. Ибрагимова, ор.cit., s. 324.

${ }^{88}$ А. И. Иванов, Восстание в Чечне в 1877 г., s. 181; С. А. А. Исаев, ор.cit., s. 281-286.

${ }^{89}$ Obszary nad rzeką Terek. Naibstwo, tutaj: jednostka podziału terytorialnego, zarządzana przez naiba - A. S.

90 3. Х. Ибрагимова, ор.cit., s. 325.

${ }^{91}$ С.-А. А. Исаев, оp.cit., s. 289-301.
} 
nad przywódcami. Z 18 osób postawionych przed sądem 14 skazano na karę śmierci przez powieszenie, a pozostali otrzymali wyroki 20 lat katorgi. Tysiące czeczeńskich rodzin przesiedlono na równiny. 500 Czeczenów i Dagestańczyków skazano na bezterminową katorgę; 400 osób zesłano do guberni centralnych (tulska, kałuska i riazańska), 500 do północnowschodnich (nowogrodzka, ołoniecka i wołogodzka). Większa część górali kaukaskich ginęła $\mathrm{w}$ miejscach zsyłki lub zamknięcia. Na przykład z 1625 górali skierowanych do guberni nowogrodzkiej już w ciągu pierwszych kilku miesięcy zmarło 429, a 74 było ciężko chorych ${ }^{92}$. W 1886 r. w Czeczenii były odnotowywane wystąpienia spowodowane przez spis ludności, który przeprowadzono w celu zmuszenia górali kaukaskich do wypełniania obowiązku wojskowego ${ }^{93}$.

Pod koniec XIX i na początku XX wieku w górskich okręgach obwodu tereckiego rozszerza się zjawisko ",abreczstwa" ${ }^{94}$, które przybiera do tego stopnia na sile, iż Władykaukaska Duma w 1905 r. organizuje specjalną komisję zajmującą się tą kwestią. Jednym z najbardziej znanych przedstawicieli tego ruchu w Czeczenii był Zelimchan Guszmazukajew ze wsi Characzoj. Z rozkazu głównodowodzącego wojskami Kaukaskiego Okręgu Wojskowego, generała-adiutanta hr. I. I. Woroncowa-Daszkowa z 14 listopada 1910 r., rozpoczęło się zsyłanie tych mieszkańców okręgów nazrańskiego i wiedeńskiego, którzy ukrywali bądź okazywali pomoc abrekowi i jego bliskim. Dziesięć osób zostało osadzonych w więzieniu ${ }^{95}$. Wśród zesłańców byli starcy, kobiety i dzieci.

O wspieranie abreka Zelimchana oskarżono zikrystów. Aresztowano i zesłano cieszących się największym autorytetem szejków, takich jak Batał-Hadżi Biełchorojew, mułła Mahomet, Abdul-Aziz Szaptukajew, Czimmirza-Hadżi i inni. Ciężkie represje wobec ludności dotknęły Czeczenię w początkach XX wieku, zwłaszcza w latach 1911-1913; według niektórych danych w tym okresie około 100 tysięcy Czeczeńców wyemigrowało do Turcji ${ }^{96}$.

Większą część górali, którzy znaleźli się w polu obserwacji organów represji, stanowili uczestnicy wydarzeń rewolucyjnych. Zaliczał się do nich słynny inguski krzewiciel oświaty A. G. Dołgijew. W czasie studiów na Wydziale Prawa Cesarskiego Uniwersytetu w Sankt Peters-

\footnotetext{
92 3. Х. Ибрагимова, op.cit., s. 344-345.

${ }_{93}$ Zob. Г. Н. Казбек, Военно-статистическое описание Терской области, Тифлис 1888, s. 11.

${ }^{94}$ Abrek - w folklorze kaukaskim postać samotnego, szlachetnego wojownika. Według władz carskich abreczstwo było formą rozbójnictwa.

${ }_{95}$ РГВИА, фонд 400, опис 1, дело 3923, k. 1-15, 20-25.

96 3. Х. Ибрагимова, ор.cit., s. 363.
} 
burgu wiosną 1869 r. wziął on udział w wystąpieniach studenckich, za co został aresztowany i przez miesiąc był przetrzymywany w twierdzy Pietropawłowskiej. 12 kwietnia 1869 r. Dołgijew został odesłany pod nadzór policji do obwodu tereckiego na wieś Dachkilg-Jurt (obecnie wieś Dołakowo). W 1873 r. wstąpił do Akademii Medyczno-Chirurgicznej w Sankt Petersburgu. Tutaj stał się aktywnym uczestnikiem kół studenckich i przyłączył się do ruchu narodnickiego. Ponownie aresztowany, został powtórnie zesłany do obwodu tereckiego i stąd - na Zakaukazie (Tyflis $)^{97}$. Analogicznie wyglądały losy wielu zawodowych rewolucjonistów pochodzących z ludów górskich.

Znacznie wzrosła liczba górali kaukaskich zesłanych i skazanych na więzienie na początku XX wieku, kiedy w centrach przemysłowych i wiejskich aułach Północnego Kaukazu, podobnie jak w całej Rosji, odbyły się masowe wystąpienia. W tym czasie na Syberii znajdowały się setki zesłanych górali.

Jak można było się przekonać, uznani za winnych różnego rodzaju przestępstw górale byli zsyłani nie tylko poza granice Kaukazu, ale też do innych jego obwodów, krajów lub rejonów w obrębie tego samego okręgu. W 1873 r. według wytycznych naczelnika obwodu tereckiego generała-lejtnanta M. T. Łoris-Mielikowa miejscem zesłania stała się wyspa Czeczeń, znajdująca się na Morzu Kaspijskim. Po upływie dziesięciu lat, w związku z wprowadzeniem w kwietniu 1883 r. Instytucji Zarządzającej Krajem Kaukaskim, jako miejsce osiedlenia „występnych osób” został wyznaczony były okręg kizliarski. Dla osób, które popełniły cięższe przestępstwa, miejscem zesłania pozostawała nadal wyspa Czeczeń. Stworzono na niej oddział ochrony złożony z siedmiu kozaków i jednego uriadnika ${ }^{98}$. Za racjonalne i spełniające funkcję odstraszającą uznał to miejsce zsyłki „bardziej występnych” górali kaukaskich główny naczelnik i dowódca wojsk na Kaukazie książę A. M. Dondukow-Korsakow. Na jego wniosek zaczęto tu wysyłać nie tylko górali obwodu tereckiego, ale również mieszkańców obwodu karskiego i Kraju Zakaukaskiego, włączając w to zesłańców bezterminowych. Na dostosowanie koszar przeznaczono z dochodów od grzywien 4050 rubli $^{99}$.

W raporcie naczelnika obwodu tereckiego generała-lejtnanta S. W. Kochanowa, z dnia 21 września 1896 r., który był zaadresowany do naczelnika sztabu Kaukaskiego Okręgu Wojskowego, szczerze stwierdzono, iż nie wszyscy zesłańcy popełnili przestępstwa, które powinny pociągnąć

${ }_{97}$ Zob. М. Амирова, Просветитель из ингушей, [w:] http://www.ingush.ru/ serdalo3_3.asp. [dostęp: 8 V 2013 r.].

${ }^{98}$ Podoficer kozacki lub policyjny - A. S.

${ }^{99}$ РГВИА, фонд 1300, опис 4, дело 1412, k. 37-37v. 
za sobą tego typu karę. Kochanow rozpoczął starania o uwolnienie niektórych aresztantów oraz, ogólnie, o zniesienie kary zesłania na wyspę. Do raportu była dołączona lista górali z obwodu karskiego i tereckiego, osiedlonych na wyspie - stan z września 1896 r. ${ }^{100}$

Jak pokazuje tabela 2, główna część zesłańców składała się z mieszkańców obwodu tereckiego. Często trafiały tu osoby na mocy wyroku wydanego przez społeczność wiejską (z określonego aułu) bądź też przez zebranie przedstawicieli ludów lokalnych domagających się od swojej administracji zesłania „występnych”, którzy nie reagowali właściwie na publiczne nagany i działania wychowawcze. Na przykład w ostatnim dwudziestopięcioleciu XIX wieku takiej kary na swoich zebraniach żądali Ingusze dla członków lokalnych społeczności, którzy naruszyli zakazy kradzieży, porywania dziewic itp.

Tabela 2. Liczba osadzonych z północnego Kaukazu na wyspie Czeczeń w 1896 r.

\begin{tabular}{|c|c|c|c|c|}
\hline \multirow{2}{*}{$\begin{array}{c}\text { Z jakiego } \\
\text { obwodu }\end{array}$} & \multirow{2}{*}{$\begin{array}{c}\text { Stan } \\
\text { z } 1 \text { maja } 1896 \text { r. }\end{array}$} & \multicolumn{2}{|c|}{ W przeciągu 4 miesięcy } & \multirow{2}{*}{$\begin{array}{c}\text { Stan na } \\
1 \text { września } 1896 \text { r. }\end{array}$} \\
\hline & & $\begin{array}{l}\text { przybyło } \\
\text { na wyspę }\end{array}$ & $\begin{array}{c}\text { ubyło } \\
\text { z wyspy }\end{array}$ & \\
\hline Obwód karski & 4 & & & 4 \\
\hline Obwód terski & 49 & 6 & 37 & 18 \\
\hline Ogółem & 53 & 6 & 37 & 22 \\
\hline
\end{tabular}

Sytuacja aresztantów i zesłańców spośród górali kaukaskich zawsze była ciężka. Pod wieloma względami był to rezultat samowoli władz więziennych. „W konsekwencji takiej polityki państwowej - pisze M. N. Garnet - Żydzi, Łotysze, Polacy, Ormianie, Gruzini i inni, oprócz kary w miejscach pozbawienia wolności, musieli doświadczać jeszcze ciężkich i poniżających moralnych męczarni. W szczególnie trudnych warunkach znajdowali się południowcy: górale kaukascy, Gruzini, Ormianie itd. W celu odbycia kary związanej z długoterminowym pozbawieniem wolności byli oni wysyłani do guberni o zimnym klimacie, w których groziło im zachorowanie na gruźlicę. $W$ takich przypadkach więzienie stawało się dla nich zamaskowanym wyrokiem śmierci"101. W. N. Nikitin opisuje zdarzenie, do którego doszło $\mathrm{w}$ jednej $\mathrm{z}$ aresztanckich rot. Młody Czerkies, całkowicie wyniszczony zdrowotnie $\mathrm{w}$ niewoli, za wstawiennictwem

${ }^{100}$ Ibidem, k. 4.

${ }^{101}$ M. Н. Гарнет, op.cit., s. 392. 
ważnych osobistości uzyskał ułaskawienie. Jednak bezpośredni naczelnik postanowił przed wypuszczeniem poznęcać się nad więźniem. „Naczelnik polecił przynieść czerkieski strój ze wszystkimi dodatkami, rozkazał Czerkiesowi, aby ten przebrał się i zaczął go drażnić, mówiąc: «O, chciałbyś teraz dosiąść rączego konia, wrócić do domu, w góry, by porobić kindżałem». Czerkies słuchał i słuchał, azjatycka krew zawrzała w nim jak we wzburzonym potoku, wpadł we wściekłość i zranił kindżałem naczelnika. Za to został skazany na praszczęta ${ }^{102} \mathrm{i}$ umarł pod uderzeniami pałką"103.

Rząd w trybie ustawowym określał etapy i zasady zsyłania grup aresztantów oraz osadzania zesłańców i aresztantów. Pod tym względem szczególne znaczenie miały akty normatywne, zatwierdzone jeszcze w dniu 22 lipca 1822 r.: Statut o zesłańcach i Statut o etapach ${ }^{104}$. Statut o zesłańcach funkcjonował nadal ze zmianami i uzupełnieniami na początku XX w. ${ }^{105}$

Do przeprowadzania aresztantów z Kraju Zakaukaskiego i północno-wschodniego Kaukazu do Centralnej Rosji, na Syberię i z powrotem, zaczęto wykorzystywać Gruzińską Drogę Wojenną. Według danych S. Maksymowa aresztanci piechotą szli z Tyflisu 143 dni, a ze Stawropola (przez Charków) $-100^{106}$.

Proces transportu aresztantów i zesłańców przyspieszył wraz z budową w Rosji dróg żelaznych. Opłaty związane z przewożeniem aresztantów przy pomocy linii kolejowych zostały określone w specjalnym regulaminie, zatwierdzonym 21 marca $1877 \mathrm{r} .{ }^{107}$

Chłód, wilgoć, zatęchłe powietrze, antysanitarne warunki, złe żywienie $w$ miejscach zamknięcia i zesłania, w połączeniu $z$ negatywnym stosunkiem nie tylko ze strony pozostałych więźniów, ale również kierownictwa sprawiały, że góralom kaukaskim pozostawało niewiele szans na powrót do ojczyzny. Pomimo podjętych działań, mających na celu wzmocnienie ochrony na etapach poruszania się grup więźniów i w miejscach przetrzymywania pod strażą, odnotowywano wysoki procent uciekinierów.

${ }^{102}$ Kara stosowana w wojsku rosyjskim do końca XIX wieku. Polegała ona na przepędzeniu skazanego przez podwójny szpaler żołnierzy, którzy uderzali go kijami, pałkami, rózgami itp. Karę często powtarzano, po około 300-400 uderzeniach więzień zazwyczaj umierał.

${ }^{103}$ В. Н. Никитин, op.cit., s. 16.

${ }^{104}$ ПСЗРИ, Собрание первое, t. 38, С.-Петербург 1830, ст. 29.128, 29.129, s. 433-468, 469-486.

${ }^{105}$ Zob.. Устав о ссылльныхx, [w:] http://rus-sky.com/history/library/vol.14/vol.14.5.htm. [dostęp: 8 V 2013 r.].

${ }^{106}$ C. Максимов, Сибирь и каторга, cz. 1, С.-Петербург 1871, s. 368.

107 Терский календарь на 1904 год, s. 153-154. 
Znacznie ułatwiła góralom kaukaskim ucieczkę kolej syberyjska, która przyspieszała im powrót na Kaukaz ${ }^{108}$. Trudno określić liczbę zbiegłych górali, ale to, iż było ich niemało, potwierdzają archiwalne dokumenty.

W niniejszym artykule podjęta została próba zarysowania tylko niektórych aspektów tematu. Jednak jego wielowymiarowy charakter, obecność wielu jeszcze niezbadanych dokumentów i materiałów, ogólne znaczenie dla badania warunków życia górali kaukaskich w ramach Imperium Rosyjskiego i inne czynniki uzasadniają konieczność dokładniejszych badań i głębokiej naukowej analizy. Szczególne zainteresowanie wzbudza kwestia geografii zesłań i osadzania w więzieniu górali kaukaskich, liczebność aresztantów i zesłańców, ich skład według płci i wieku, narodowość, terminy i warunki odbywania kary.

\section{BIBLIOGRAFIA:}

Амирова М., Просветитель из ингушей, [w:] http://www.ingush.ru/serdalo3_3.asp. Ахмадов Ш., Национальное освободительное движение в Чечне и на Северном Кавказе

под предводительством имама Мансура в 1785-1791 22., [w:] Чеченцьв: история и современность, ред. Ю. А. Айдаева, Москва 1996.

Батчаева М. К., Деятельность „Ставропольского попечительного о тюрьмах комитета" в 40-70-х г2. XIX в., [w:] http://cyberleninka.ru/article/n/deyatelnost-stavropolskogopopechitelnogo-o-tyurmah-komiteta-v-40-70-h-gg-xix-veka.

Гарнет М. Н., История циарской тюрьмиь, t. 3, 1870-1900, Москва 1961.

Ерошкин Н. П., История государственных учреждений дореволюиционной России, Москва 1997.

Ибрагимова 3. Х., Чеченский народ в Российской империи: адаптациинный период, Москва 2006.

Иванов А. И., Восстание в Чечне в 1877 2., „Вопросы Истории” 1940, nr 12.

Иванов А. И., Национально-освободительные движения в Чечне и Дагестане в 60-70-х ХІХ в., „Исторические записки” 1941, nr 12.

Исаев С. А. А., Присоединение Чечни к России. Аграрная политика изаризма и народные движения в крае в XIX в., Москва 1998, maszynopis pracy kandydackiej przechowywany w Российской Государственной Библиотеке.

Казбек Г. Н., Военно-статистическое описание Терской области, Тифлис 1888.

Максимов С., Сибирь и каторга, сz. 1, С.-Петербург 1871.

Мартиросиан Г. К., История Ингушии. Материаль, [w:] Ингушский НИИ краеведения, Орджоникидзе 1933.

Мужухоева Э. Д., Административная политика цุаризма в Чечено-Ингушетии во второй половине XIX - нач. XX в., Москва 1989, maszynopis pracy kandydackiej przechowywany w Российской Государственной Библиотеке.

Мулукаев Р. С., Малыгин А. Я., Епифанов А. Е., История отечественных органов внутренних дел: учебник для вузов, Москва 2005.

Мусаев А., Шейх Мансур, Москва 2007.

108 3. Х. Ибрагимова, оp.cit., s. 289. 
Никитин В. Н., Быт военных арестантов в крепостях, С.-Петербург 1873.

Пузиков В., Тюрьмы Ставропольской губернии, [w:] http://www.proza.ru/2011/12/27/623. Романовский Д. И., Кавказ и Кавказская война, С.Петербург 1860.

Россия и Кавказа сквозь два столетия, составиди и подготовиди Г. Г. Аисицына и Я. А. Гордон, Санкт Петербург 2001.

Тимофеев В., Уголовно-исполнительная систела России - цифры, факты и события,

[w:] http://readr.ru/v-timofeev-ugolovno-ispolnitelnaya-sistema-rossii-cifri-fakti-i-sobitiya.html?page= 12\#ixzz2eSyjnbCf.

Титов В. Ю., Хрестоматия по истории государства и права России, Москва 1998.

Фадеев А. П., Россия и Кавказ в первой трети ХІХ в., Москва 1960.

http://constitution.garant.ru/history/act1600-1918/2350/\#sub_para_N_23. http://drink.dax. ru/turma/turem_30.shtml.

\section{ABSTRACT:}

The aim of the present article is to attempt to highlight selected aspects of functioning of Caucasian highlanders in the Russian Empire. Due to the multi-faceted nature of this problem and a wealth of unexplored documents and materials, the issue of Caucasian highlanders in Russia demands more comprehensive investigations and analyses. Most importantly, geographic specification of places of exile and imprisonment of highlanders, the number of persons arrested and exiled, the age of the convicts, their nationality, prison time and conditions demand special attention.

Key words: Russian Empire, Caucasus, Chechens, Ingush, imprisonment, exile

\section{NOTA O AUTORZE:}

Malika Arsanukaeva - docent Rosyjskiej Akademii Prawnej i pracownik naukowy Moskiewskiej Państwowej Akademii Prawniczej. W jej kręgu zainteresowań znajduje się status prawny Czeczenii $\mathrm{w}$ imperium rosyjskim $\mathrm{w}$ XIX-XX w. oraz funkcjonowanie sądownictwa w Rosji przed 1917 r. e-mail: az1man2@mail.ru 